\title{
MONITORING SYSTEM ON VILLAGE FUND: SYNERGY BETWEEN COMMUNITIES AND REGULATORS (CASE STUDY ON BOGOR DISTRICT GOVERNMENT)
}

\author{
Rochman Marota ${ }^{\left.a^{*}\right)}$, Asep Alipudin ${ }^{a)}$

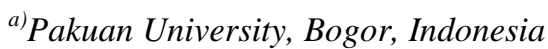 \\ ${ }^{*}$ Corresponding Author: rochmanmarota@yahoo.com
}

Article history: received 10 June 2019; revised 15 July 2019; accepted 26 August 2019

\begin{abstract}
The Village Law gives new meaning to trust by viewing the village as an institution equal to the regional government. Not only as an institution providing letters or government accomplices but an institution that independently and has the task of maintaining the welfare of the small unit in the community. These consequences provide a view of the professionalism of performance that can be monitored transparently and accountably. The urgency of this research lies in its objectives and benefits for the government and village officials, namely to provide a complete and factual picture of the system of monitoring on village funds from all aspects of development, management, accountability, and evaluation as well as strengthening the capabilities of village officials in managing funds and overseeing programs funded specifically by village funds and village development in general. This study concludes that there is a relationship between the stages of development, management and financial accountability starting from the process of planning, implementing, administering and reporting village funds to the monitoring system. The expected managerial implication is the synergy in the supervision of village funds between the ministry's regulators and the community, sub-district heads, Village Consultative Body, Government Internal Control Apparatus, Audit Board of the Republic of Indonesia, and Corruption Eradication Commission to optimize transparent and accountable monitoring.
\end{abstract}

Keywords: monitoring system, village funds, monitoring synergy.

\section{INTRODUCTION}

Law No. 6 of 2014 concerning villages that was passed on 15 January 2014 gave a more certain guarantee that each village would receive funds from the government through the state and regional budgets whose numbers doubled, far above the amount that had been available in the village budget. According to the Corruption Eradication Commission report [1], villages in Indonesia will experience a new reposition and approach in the implementation of development and governance. In essence, the Village Law has a vision and engineering that gives villages broad authority in the fields of village governance, implementation of village development, village community development, and empowerment of village communities based on community initiatives, rights of origin, and village customs.

This policy has consequences for the village financial management process that should be carried out professionally, effectively and efficiently, and accountably based on the principles of good public management to avoid the risk of irregularities, fraud, and corruption. But the reality is different. Utami [2] cites the report of researcher from Indonesian Corruption Watch (ICW), Kurnia Ramadhan, who said that the village apparatus namely the Village Head and members of the Village Consultative Body were the number three perpetrators as corruption defendants in 2018, totaling 158 people the defendant or $13.61 \%$. The highest corruptors are leaders/employees of Provincial / Regency and Municipality Governments (27.48\%), Private Sector (20.84\%), Cooperatives/Farmers Communities
(7.24\%), Parliament/ legislative council $(4,57 \%)$ as well as other parties $(6.55 \%)$.

Table 1. Corruption Profession Actor in 2018

\begin{tabular}{llrr}
\hline No. & \multicolumn{1}{c}{ Profession } & $\begin{array}{c}\text { Number of } \\
\text { Cases }\end{array}$ & \% age \\
\hline 1 & Government Sector & 319 & 27,48 \\
\hline 2 & Private Sector & 242 & 20,84 \\
\hline 3 & Village Officials & 158 & 13,61 \\
\hline 4 & $\begin{array}{l}\text { Others (cooperative, farmer } \\
\text { communities) }\end{array}$ & 84 & 7,24 \\
\hline 5 & Not identified & 76 & 6,55 \\
\hline 6 & Parliament, legislative council & 53 & 4,57 \\
\hline Source: & Utami [2] & & \\
\hline
\end{tabular}

Muslih and Firmasyah [3] argued that the government and the village community need actively to take action to prevent the misuse of funds and conflict by jointly guarding the village development process. A similar sentiment was also suggested by Marota [4] and Marota and Alipudin [5] that a large number of parties and institutions overseeing the village government, in this case, the government and village officials, should see this as a reminder, guard, and guardian of the village administration. Villages are expected not to be afraid of carrying out activities with a lot of supervision. Transparency and accountability must be implemented by the village.

Village internal control must be created. It is not impossible, the Supervision System which is echoed by the central and regional governments also dropped to the Village Supervision System, of course with simpler techniques. 
Bogor district government has 40 districts and 428 villages/wards. Most of the villages in Bogor Regency are classified as self-sufficient villages, 237 villages and 191 villages are self-sufficient villages. Bogor District Original Revenue increased by 70 percent during the period 2014 to 2018, from Rp900 billion in 2014, to reach Rp1.56 trillion in 2018. The potential for villages in Bogor Regency to date is even greater when seen from the data.

Based on the background above, the main problem with village funds lies in the monitoring system. The urgency of this research lies in its objectives and benefits for the government and village officials, namely to provide a complete and factual picture of village supervision and finance from planning, management and accountability as well as strengthening the capabilities of village officials in managing funds and overseeing programs funded by village funds in a way and village development in general.

The results of previous studies relevant to this study were used to describe the position and feasibility of this research study. Putra [6] research results, supporting factors in the management of village funds are community participation, while the inhibiting factors are the quality of human resources and the lack of direct supervision by the community. Meanwhile Gayatri [7] which examines the effect of transparency and accountability on the financial management of village funds, where transparency is opening up access for the community to obtain information about planning, implementation, and accountability for village fund management; and accountability, namely the reporting and accountability of the managing team of village fund management to the community.

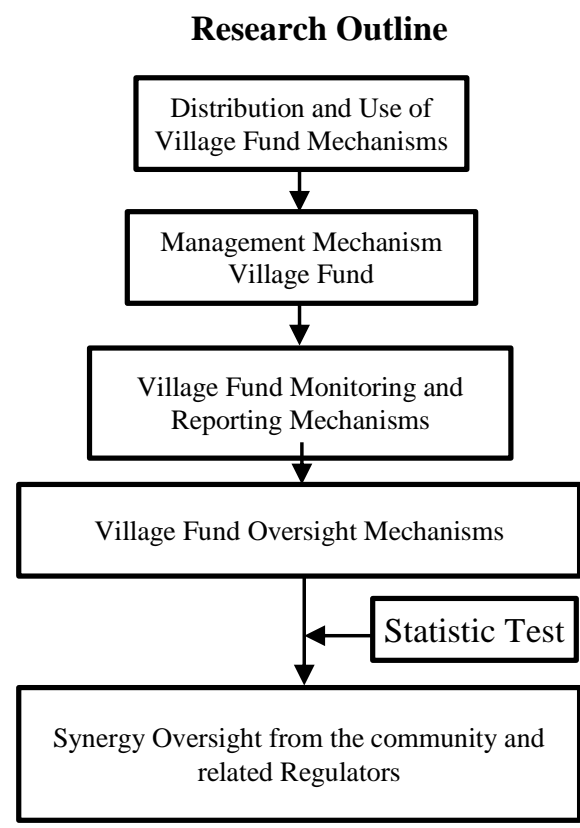

Figure 1. Research outline
This research was designed as qualitative research with a case study approach. The data sources used are primary and secondary data. Primary data were obtained through direct interviews and provided questionnaire to village heads, village secretaries, treasurer, and members of the Village Consultative Body. Secondary data were obtained from research sources by studying references that have a relationship with research objectives. After the research data is obtained, it is continued at the data analysis technique stage using multiple regression to explain the relationship between variables and the effect of independent variables on the dependent variable.

\section{RESULTS AND DISCUSSION}

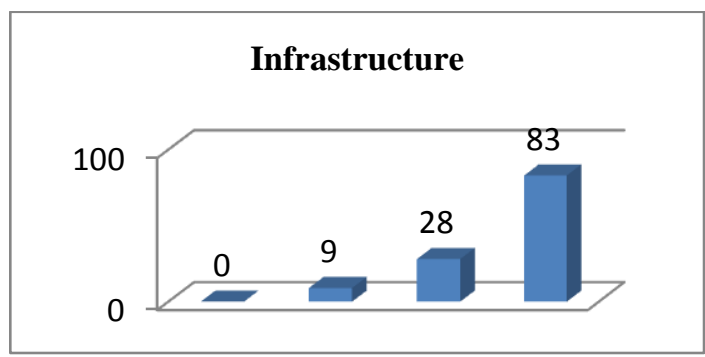

Figure 2. Infrastructure Aspect

Based on the graph above, the infrastucture aspects of village financial management have been rated as good, because the average respondent answered yes / good. This is evidenced from 30 respondents who were given 4 questions each so that a total of 120, who answered Yes from the first question were 83, who answered Mostly 28, Smaller 9, and 0 who answered No. The Village Government is considered to have implemented the Village infrastructure development program well so that from the data of development aspects have a positive impact and the existence of development that helps the community in infrastructure development, so that the results of the existing Village Government can be considered quite good in carrying out these aspects of Development.

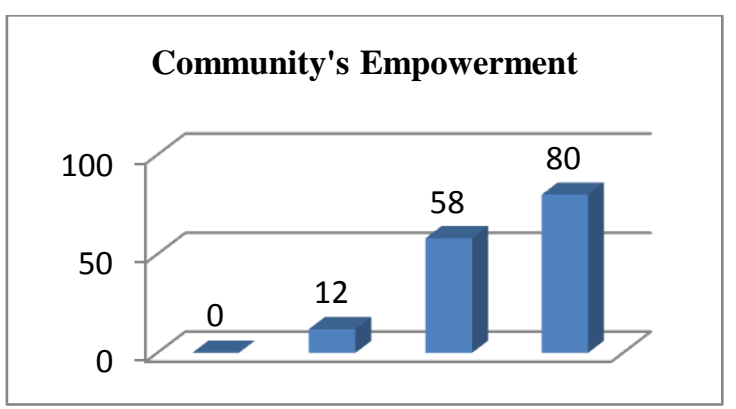

Figure 3. Community's Empowerment

Based on the graph above shows good results about Community Empowerment in the Village Fund Supervision 
System. Research results from the questionnaire submitted to 30 respondents consisting of 5 questions so that a total of 150 to represent the implementation of Community Empowerment in the Village. Community Empowerment is arguably quite good because it gets a total of 80 results for Yes, 58 Most answers, 12 Most Small answers, and 0 No answers.

This aspect of Community Empowerment means that the Village Government has implemented budget receipts and expenditures appropriately and their use is appropriate in meeting the needs associated with programs related to capital, providing education and other programs related to Community Empowerment that has been implemented by the Village Government in the framework of interests together.

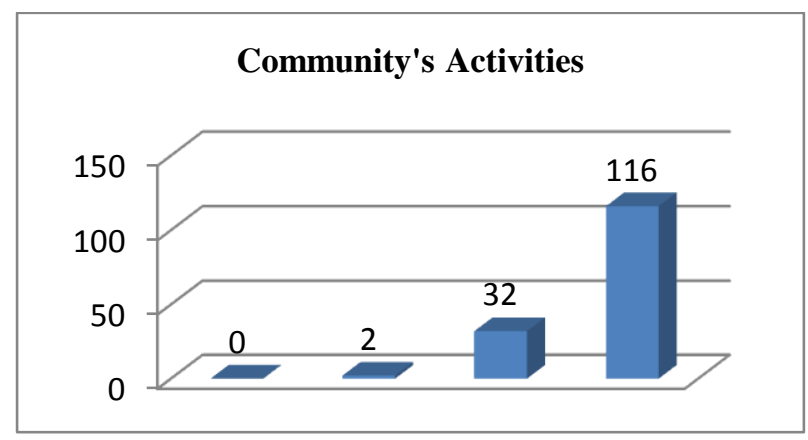

Figure 4. Community’s Activities

Based on the graph above shows quite good results about Community Activities in the Village which includes social activities. The results of the research from the questionnaire submitted contained 5 questions to 30 respondents so that 150 answers were collected, indicating that there were a total of 116 answers Yes, 32 answers "Mostly, 2 answers" A small portion, and 0 answers No.

This aspect of Community Activity is an important aspect of village development because thus the social problems that occur in the village can be resolved together because of their mutual assistance / mutual assistance. The Village Fund can be optimally utilized for things that are of common interest in the context of the welfare of the surrounding community.

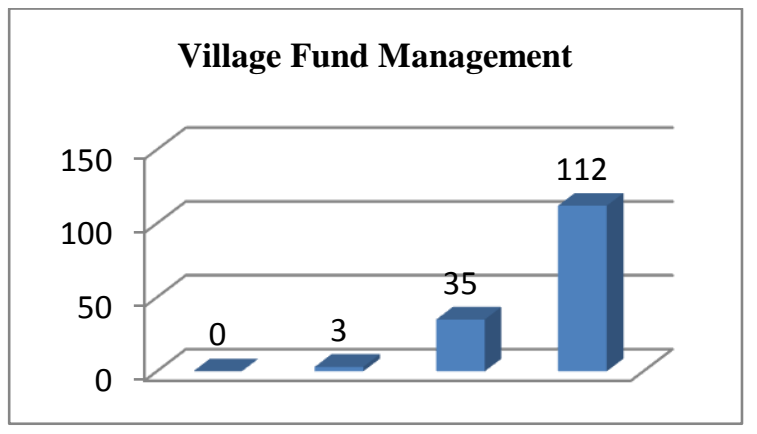

Figure 5. Village Fund Management

Based on the graph above shows good results about the Aspects of Village Fund Management, the Village
Government in reporting the use of Village Fund finances which includes the preparation, guidelines for making financial reports up to the participation of the community to check the truth of the report. The results of the study above show that of the 5 questions that represented aspects of Village Fund Management to 30 respondents collected as many as 150 answers, there were 112 answers Yes, 35 answers Mostly, 3 answers Mostly, and 0 answers No.

This aspect of Village Fund Management is important because it starts with training in preparing financial reports, guidelines for preparing financial reports, the role of village officials and the community in managing village funds.

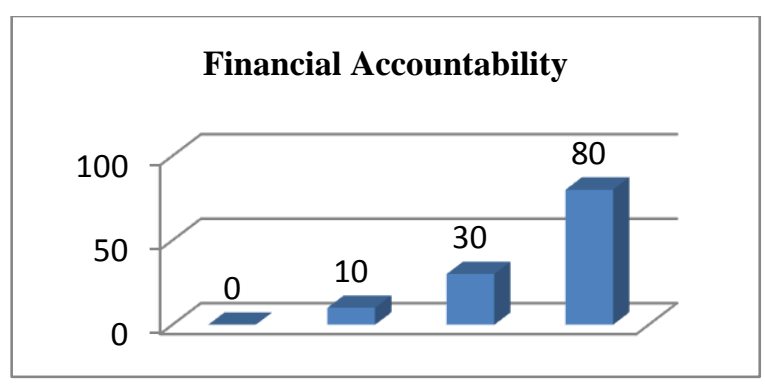

Figure 6. Financial Accountability

Based on the graph above shows good results about the Financial Accountability Aspects of the Village Government in using Village Funds for operational purposes efficiently for the benefit of the community. The results of the study above show that of the 4 questions that represent aspects of Financial Accountability to 30 respondents, there are 80 answers Yes, 30 answers Mostly, 10 answers Mostly, and 0 answers No.

This aspect of Financial Accountability is an embodiment of the accountability of funds that have been received and issued by the Village in carrying out its operational activities must be efficient and aimed at the interests and welfare of the community.

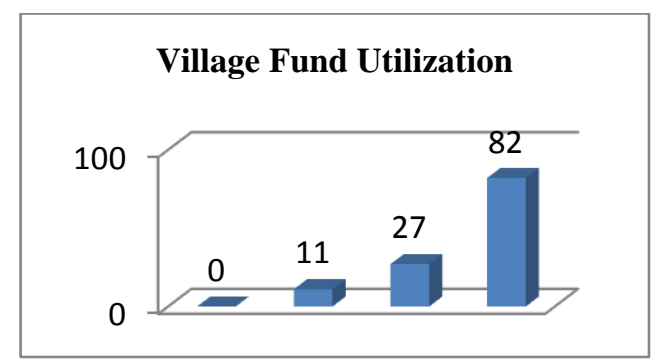

Figure 7. Village Fund Utilization

Based on the graph above shows good results about the Aspects of the Use of Village Funds, the Village Government in reporting the use of Village Fund finances which includes the use to alleviate poverty, infrastructure development and all aspects related to the interests of the community also in the framework of the welfare of the community. The results of the study above show that of the 4 questions that represent aspects of Village Fund 
Management to 30 respondents collected as many as 120 answers, there are 82 answers Yes, 27 answers Mostly, 11 answers Mostly, and 0 answers No.

The aspect of the use of the Village Fund is an aspect that must be targeted so that the problems that exist in the Village can be resolved including poverty and social inequality including infrastructure development needed by the local community to be implemented so that the purpose of the Village Fund for mutual benefit can be achieved.

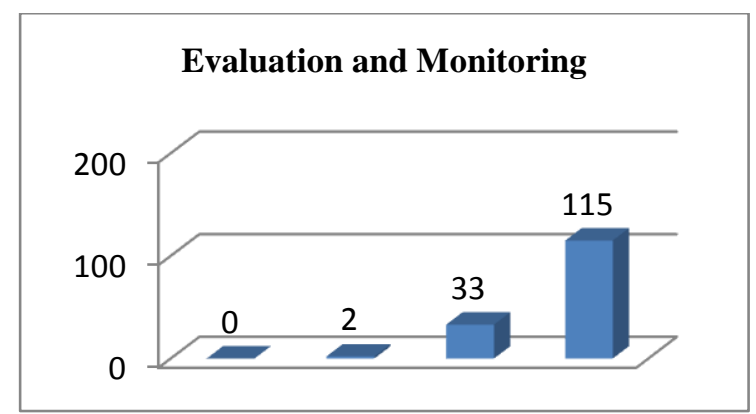

Figure 8. Evaluation and Monitoring

Based on the graph above shows good results regarding the Evaluation and Monitoring Aspects, in this aspect the Village Government in carrying out its activities must conduct a review of the effectiveness and efficiency of the activities carried out in village development. The results of the study above show that of the 5 questions representing the evaluation and supervision aspects of the 30 respondents collected as many as 150 answers, there were 115 answers Yes, 33 answers Mostly, 2 answers Mostly, and 0 answers No.

These aspects of Evaluation and Monitoring are things that will strengthen the course of the program carried out by the Village Government so that the implementation of all aspects can be created properly. With the Evaluation and Monitoring, programs that are already well controlled will certainly be endeavored to be even better, while for programs that can still be said to be not good enough, they will certainly be optimized again which will later produce better results for the benefit of the local community.

\section{Determination Test}

\begin{tabular}{|c|c|c|c|c|c|}
\hline Model & $\mathrm{R}$ & R Square & $\begin{array}{l}\text { Adjusted } \\
\text { R Square }\end{array}$ & $\begin{array}{c}\text { Std. } \\
\text { Error of } \\
\text { the } \\
\text { Estimate }\end{array}$ & $\begin{array}{l}\text { Durbin- } \\
\text { Watson }\end{array}$ \\
\hline 1 & $.887^{\mathrm{a}}$ & .786 & .718 & .82635 & 1.388 \\
\hline
\end{tabular}

The coefficient of determination (R2) aims to measure the ability of independent variables in explaining the variation of the dependent variable. $\mathrm{R} 2$ value that is getting closer to 1 means that the independent variables are increasingly able to explain the variation of the dependent variable.

Based on the test results above, it can be seen that the $\mathrm{R}$-squared value is 0.718 or $71.8 \%$. This means that in this study the variables in this study are Evaluation and Supervision, Use of Village Funds, Development, Community Empowerment, Financial Accountability, Village Fund Activities, and Village Fund Management can explain the Monitoring System variable by $71.8 \%$ while $29.2 \%$ is explained by other variables not included in this study.

\begin{tabular}{|c|c|c|c|c|c|c|}
\hline \multicolumn{7}{|c|}{ Toblo? } \\
\hline \multicolumn{2}{|c|}{ Model } & $\begin{array}{l}\text { Sum of } \\
\text { Squares }\end{array}$ & $\mathrm{df}$ & Mean Square & $\mathrm{F}$ & Sig. \\
\hline \multirow[t]{3}{*}{1} & $\begin{array}{l}\text { Regressi } \\
\text { on }\end{array}$ & 55.144 & 7 & 7.878 & 11.536 & $.000^{\mathrm{b}}$ \\
\hline & Residual & 15.023 & 22 & .683 & & \\
\hline & Total & 70.167 & 29 & & & \\
\hline
\end{tabular}

The F-test is known as the simultaneous test or test model, which is a test to see how the influence of all the independent variables together on the dependent variable. Based on the above calculation results obtained a significance value of 0,000 and significant at 0.05 . This means that Evaluation and Supervision, Use of Village Funds, Development, Community Empowerment, Financial Accountability, Village Fund Activities, and Village Fund Management jointly (simultaneously) affect the Monitoring System in Village financial management.

\section{T-Test}

\begin{tabular}{|c|c|c|c|c|c|c|}
\hline \multicolumn{7}{|c|}{$\begin{array}{r}\text { Table 4. T-test } \\
\text { Coefficients }\end{array}$} \\
\hline \multirow{2}{*}{\multicolumn{2}{|c|}{ Model }} & \multicolumn{2}{|c|}{$\begin{array}{l}\text { Unstandardized } \\
\text { Coefficients }\end{array}$} & \multirow{3}{*}{$\begin{array}{c}\text { Std } \\
\text { Coeffici } \\
\text { ents } \\
\text { Beta }\end{array}$} & \multirow[t]{2}{*}{$\mathrm{t}$} & \multirow[t]{2}{*}{ Sig. } \\
\hline & & B & $\begin{array}{l}\text { Std. } \\
\text { Error }\end{array}$ & & & \\
\hline \multirow[t]{8}{*}{1} & (Constant) & 6.609 & 3.388 & & 1.951 & .064 \\
\hline & $\begin{array}{l}\text { Infrastructur } \\
\mathrm{e}\end{array}$ & -.280 & .218 & -.230 & -1.282 & .213 \\
\hline & $\begin{array}{l}\text { Comm } \\
\text { Develop }\end{array}$ & -.240 & .103 & -.377 & -2.324 & .030 \\
\hline & $\begin{array}{l}\text { Comm } \\
\text { Activities }\end{array}$ & 1.270 & .585 & 1.148 & 2.171 & .041 \\
\hline & Fin Account & .385 & .289 & .271 & 1.330 & .197 \\
\hline & VF Mgt & -.149 & .602 & -.134 & -.248 & .806 \\
\hline & VF Utilize & -.043 & .269 & -.026 & -.161 & .873 \\
\hline & Evaluation & .121 & .588 & .105 & .206 & .839 \\
\hline
\end{tabular}

The t-test serves to show how far an independent variable affects a dependent variable. Tests in the study were carried out using a significance level of 0.05 and 2-sided $(0.05 / 2=0.025)$. Based on the results of the t-test above, the following are interpretations of the test results:

1. Provisions for taking a hypothesis are accepted or rejected based on the value of significance. If the significance is less than or equal to $0.05(\leq 0.05)$, the hypothesis is accepted. The results of these calculations explain the significance value of 0.213 . This means that 
the Development variable has no effect on the Monitoring System, but can assist monitoring in Village Financial Management.

2. The second t-test result of 0.030 explained that the Community Empowerment variable affected the monitoring system, so it was very helpful in monitoring Village Financial Management.

3. The third t-test result of 0.041 explains that the Community Activity variable influences the monitoring system, so it is very helpful in monitoring Village Financial Management.

4. The fourth t-test result of 0.041 explains that the Community Activity variable influences the monitoring system, so it is very helpful in Monitoring Village Financial Management.

5. The fifth t-test result of 0.806 explains that the Village Fund Management variable has no effect on the Monitoring System, but can assist monitoring in Village Financial Management.

6. The sixth t-test result of 0.873 explains that the variable use of Village Funds does not affect the Monitoring System, but can assist monitoring in Village Financial Management.

7. The seventh t-test result of 0.839 explains that the Evaluation and Supervision variable has no effect on the Monitoring System, but can assist monitoring in Village Financial Management.

\section{CONCLUSION}

1. Based on the results of statistical tests, village fund management carried out in the Bogor District Government area from the Infrastructure Aspect to the Evaluation and Monitoring Aspects has been going well, meaning that the Village Government in carrying out its obligations has fulfilled the stipulated stipulations. This can be seen from the answers to the questionnaire with the average answer is "Yes / Good".

2. The Infrastructure Development Aspect also shows positive results on the Village Fund Supervision System, meaning that the Development Aspect in the Village Government has run quite well according to the rules of the regulator.

3. The Community Empowerment Aspect also shows significant positive results on the Village Fund Supervision System, meaning that the Village Government Community Empowerment Aspect has been carried out very well following the rules set by the regulator.

4. The Community Activity Aspect also showed significant positive results on the Village Fund Supervision System, meaning that the Community Activity Aspect in the Village Government that was done was very good following the rules set by the regulator.

5. The Financial Accountability Aspect also shows positive results on the Village Fund Supervision System, meaning that the Financial Accountability Aspect in the Village
Government is quite good following the rules set by the regulator.

6. The Village Fund Management Aspect also shows positive results on the Village Fund Supervision System, meaning that the Village Fund Management Aspect in the Village Government is quite good following the rules set by the regulator.

7. The Aspect of Using Village Funds also shows positive results on the Village Fund Supervision System, meaning that the Aspect of Using Village Funds in the Village Government is good enough following the rules set by the regulator.

8. Evaluation and Monitoring Aspects that show positive results on the Village Fund Monitoring System, meaning that the Evaluation and Monitoring Aspects in the Village Government are good enough.

\section{Managerial Implications}

Village Fund Monitoring Synergy

The Central Government through the Ministry of Finance [8], has conducted synergies, both between ministries and with the regions in the context of implementing a gradual implementation of Village Fund monitoring by involving community participation, supervisory apparatus in the regions, up to the Corruption Eradication Commission. The synergy of monitoring includes:

1. Ministry of Domestic Affairs Encourage Regents/Mayors to:

a) Facilitate the preparation of Government Work Plan and Revenue and Expenditures Budget of the villages,

b) Optimize the rule of district/city and district Regional Apparatus Organizations in assisting the implementation of the Village Government,

c) Empower functional supervisors,

d) Fostering the implementation of information disclosure in the village.

2. Ministry of Finance

a) Conduct Training and supervision of Village Financial Management Apparatuses.

b) Conduct the first evaluation of Village Fund Allocation budgeting in local elections/regional budgets.

c) Conduct the second of the allocation of Village Fund Allocation in the regional budgets.

d) Channeling Village Funds.

e) Monitoring and Evaluation of Distributing Village Funds.

3. Ministry of Villages, Development and Undeveloped Villages

a) Formulate mentoring framework for increasing the capacity of village communities.

b) Monitoring and evaluating the performance of professional counterparts every quarter.

The synergy of all regulators, namely the Ministry of Finance, the Ministry of Domestic Affairs, and the Ministry of Villages, Development and Undeveloped Villages in monitoring and evaluating: 
a) Regents of regents/mayors regarding the procedure for distribution and determination of the amount of the Village Fund for each village.

b) realization of distribution from Regional General Cash Accounts to Regional Cash Account.

c) the remaining Village Funds in the Regional General Cash Accounts to Regional Cash Account.

d) use of the Village Fund in accordance with established priorities.

e) achievement of the results of the use of Village Funds.

Besides, monitoring of village funds can also come from:

1. Village Communities: monitor the implementation of Village development and implementation of Village governance.

2. Head of District: supervises villages through facilitation activities

3. Village Consultative Body: supervises the performance of the Village Head.

4. Government Internal Control Apparatus: Supervises Village Financial Management, Utilization of Village Assets and Village Administration.

5. Audit Board of the Republic of Indonesia: audits the management of state finances following the principles of governance of state finances (administrative audits)

6. Corruption Eradication Commission: examines the management and financial responsibility of the state which has been identified as a criminal act of corruption

\section{Suggestions}

Suggestion for the next research is to expand the research object, namely all villages in Bogor District Government, West Java Province, and even the whole of Indonesia so that a generalization of the village fund monitoring system can be made.

\section{Acknowledgement}

This research and publication were funded by Ministry of Research, Technology and High Education based on letter No. 7/E/KPT/2019 and contract No. 110/SP2H/LT/DRPM /2019 and No. 2654/L4/PP/2019.

\section{REFERENCES}

[1] [KPK] Komisi Pemberantasan Korupsi. 2015. Laporan Hasil Kajian Pengelolaan Keuangan Desa: Alokasi Dana Desa dan Dana Desa. Jakarta.

[2] Utami, Sinar Putri S. 2019. Perangkat Desa Terseret Korupsi Jadi Tren Baru di 2018. Media Online Kontan, Jakarta. https://nasional.kontan.co.id/news/perangkat-desaterseret-korupsi-jadi-tren-baru-di-2018

[3] Muslih, Fitria dan Firmasyah. 2015. Modul Pelatihan Pengawasan Pembangunan Desa dan Keuangan
Desa, Penerbit Pattiro Jeka, Jeneponto, Sulawesi Selatan.

[4] Marota R, Mulyani S, Sukmadilaga C, Mauludina A. 2018. Monitoring System of Village Fund Allocation by Village Officials. International Conference on "Medical, Medicine \& Health Sciences", EIBAANIMH, 17-18 November 2018, South Korea

[5] Marota R dan Alipudin A. 2019. Sistem Pengawasan Pengelolaan Keuangan Desa. Jurnal Ilmiah Akuntansi Fakultas Ekonomi/JIAFE Vol 5(1). Penerbit Fakultas Ekonomi Universitas Pakuan. Bogor

[6] Putra CK, Pratiwi RN, Suwondo. 2016. Pengelolaan Alokasi Dana Desa dalam Pemberdayaan Masyarakat Desa (Studi pada Desa Wonorejo Kecamatan Singosari Kabupaten Malang). Jurnal Administrasi Publik (JAP) 1(6):1203-1212.

[7] Gayatri, Latrini Made Yeni dan Widhiyani Ni Luh Sari. 2017. Transparansi dan Akuntabilitas Pengelolaan Keuangan Dana Desa untuk Mendorong Kemandirian Masyarakat Pedesaan. Jurnal Ekonomi Kuantitatif Terapan 10 (2): 175-182.

[8] Kementerian Keuangan Republik Indonesia. 2017. Buku Saku Dana Desa: Dana Desa Untuk Kesejahteraan Rakyat. Jakarta. 